\title{
ANALISIS PENGARUH KUALITAS PELAYANAN, PROMOSI DAN HARGA TERHADAP KEPUASAN PELANGGAN PADA JASA PENGIRIMAN BARANG JNE DI BESUKI
}

\author{
Kurnia Firmanda Jayanti' ${ }^{1}$, Feti Fatimah ${ }^{2}$, Ahmad Izudin ${ }^{3}$ \\ Studi Manajemen, Fakultas Ekonomi Dan Bisnis Universitas \\ Muhammadiyah Jember ${ }^{1,23}$ \\ Email : kuriafj@gmail.com, fetifatimah@unmuhjember.ac.id, \\ izzudin@unmuhjember.ac.id
}

\begin{abstract}
This research was conducted to see the effect of service quality, promotion and price on customer satisfaction. This research was conducted at the Besuki branch of JNE. Sampling was done by random sampling technique where all the population was taken at random to be the research sample. This is done to increase customer satisfaction at JNE Besuki branch through service quality, promotion and price. The analytical tool used is multiple linear regression to determine service quality, promotion and price on customer satisfaction. The results show that service quality affects customer satisfaction, promotion affects customer satisfaction, price affects customer satisfaction.
\end{abstract}

Keyword : service quality, promotion, price, customer satisfaction

\section{Pendahuluan}

Pada masa saat ini proses pengiriman barang sangat sering dan sangat di butuhkanoleh setiap masyarakat dan proses pengirimanpun berlangsung cepat. Bila sebelumnya masyarakat melakukan transaksi jual beli secara langsung atau online di sebut (konvensional). Di era yang semakin maju ini, keperluan seseorang semakin meningkat, dalam aktivitasnya sehari-hari pada umumnya masyarakat dilakukan secara online. Masyarakat pada zaman sekarang banyak mengguakan pasar dunia maya atau transaksi jual beli online untuk memenuhi kebutuhannya. Banyaknya pengiriman dokumen-dokumen dan penjualan secara online menyebabkan tingginya frekuensi pengiriman barang menggunakan jasa pengiriman yang disediakan oleh perusahaan.

Hal inilah yang merangsang pasar jasa pengiriman barang semakin berkembang. Sehingga persaingan antar jasa pengiriman baik perusahaan dari luar negeri maupun dalam negeri menjadi sengit. Sehingga konsumen lebih memilih jasa pengiriman barang yang dipercaya, pelayanan yang diberikan dengan baik, menawarkan promosi serta harga yang terjangkau untuk memudahkan konsumen dalam hal untuk mendistribusikan barang dengan jarak jauh namun mudah untuk disalurkan dengan mudah. Selain itu perusahaan harus menerapkan berbagai 
strategi yang tepat untuk dapat menciptakan keunggulan dan mampu bersaing dengan perusahaan lain.

Menurut Tjiptono,2011) jasa merupakan jenis usaha yang memegang peranan vital perekonomian dunia, pelayanan yang baik juga akan mempengaruhi seseorang untuk memilih suatu jasa pengiriman, kualitas jasa juga ada hubungannya dengan pangsa pasar, reputasi perusahaan serta penetapan harga. Kualitas jasa dapat meningkatkan suatu penjualan dan dapat mempertahankan pelanggan sehingga akan mempengaruhi keuntungan perusahaan. Untuk memasarkan suatu produknya perusahaan harus menyebarkan informasi serta rancangan tentang kehadiran produknya, karakteristik produk, ketersediaan produk, dan kondisi produk serta manfaat yang diperoleh ketika menggunakan produk tersebut. Dan strategi promosi digunakan untuk mengenalkan suatu produk.

Menurut Kotler (2013) yang mendefinisikan bahwa harga adalah sejumlah uang yang dibagikan atas suatu produk atau jasa atau sejumlah dari nilai yang dikeluarkan oleh para pelanggan untuk memperoleh manfaat atau menggunakan suatu produk atau jasa. Sedangkan menurut Swastha (2015) yang mengartikan bahwa harga adalah sesuatu hal yang dibutuhkan untuk mendapatkan sesuatu kombinasi antara pelayanan yang ditambah produk dengan membayarkan sejumlah uang yang telah menjadi patokan. Harga juga merupakan satu-satunya hal yang menajdi unsur bauran pemasaran yang mampu mendatangkan keuntungan bagi setiap perusahaan.

Usaha di bidang jasa pengiriman adalah usaha yang berhubungan dengan proses pengiriman barang kepada konsumen. Dengan melihat keadaan saat ini usaha di bidang pengiriman ini sangatlah besar karena melihat kebutuhan konsumen yang semakin hari semakin naik namun keadaan pandemic ini disaat semua orang dibatasi untuk berada di luar rumah namun permintaan semakin naik seperti untuk kebutuhan rumah tangga atau berbelanja secara online maka alternatif baiknya yaitu dengan mengirimkan barang yang kita butuhkan menggunakan jasa pengiriman barang.

\section{Metode Penelitian}

Hipotesis merupakan jawaban sementara terhadap rumusan masalah. Karena sifatnya masih sementara, maka perlu dibuktikan kebenarannya melalui data empirik yang terkumpul (Sugiyono,2017).

Menurut Sugiyono,2016 populasi merupakan wilayah yang generalisasi yang artinya terdiri atas obyek atau subyek yang mempunyai kualitas dan karakteristik tertentu yang ditetapkan oleh peneliti untuk selanjutnya dipelajari dan kemudian dibuat kesimpulannya.

Menurut Sugiyono (2013) yang menyatakan bahwa sampel adalah bagian dari jumlah dan karakteristik yang dimiliki oleh populasi tersebut. Dalam suatu pengambilan sampel penelitian harus yang benar-benar representative yang artinya sampel yang telah diambil harus bisa mewakilkan keseluruhan jumlah populasi yang ada. Sampel dalam penelitian ini adalah konsumen pengguna jasa JNE di besuki. Penentu sampel dalam penelitian ini menggunakan kuisioner dan angket yang ditentukan berdasarkan jumlah indicator yang dikalikan 5-10. Penelitian ini menggunakan 15 indikator dan menggunakan faktor yang di kali 5 karna indicator 
penelitian hanya berjumlah 15 , maka jumlah sampel penelitian ini telah di tetapkan sebesar 15 x $5=75$.

Berikut ini perhitungan jumlah sampel berdasarkan pendapat (arikunto,2016:146) :

Sampel = Jumlah Indikator X 5

$$
\begin{aligned}
& =15 \times 5 \\
& =75 \text { sampel }
\end{aligned}
$$

\section{Hasil Penelitian}

Model persamaan regresi yang baik adalah yang memenuhi persyaratan asumsi klasik, antara lain semua data berdistribusi secara normal, model harus bebas dari gejala multikolenieritas dan juga terbebas dari heteroskedastisitas. Dari analisis sebelumnya telah terbukti bahwa model persamaan yang diajukan dalam penelitian ini telah memenuhi persyaratan asumsi klasik sehingga model persamaan dalam penelitian ini sudah di anggap secara baik. Untuk menguji hipotesis tentang pengaruh secara parsial variabel bebas terhadap variabel terikat yaitu dengan penggunaan analisis regresi. Berdasarkan estimasi regresi linier berganda dengan program SPSS versi 20,0 diperoleh hasil sebagai berikut :

Tabel 4.12 Hasil Uji Regresi Linier Berganda

\begin{tabular}{lll}
\hline No & Variabel & Koefisien Regresi \\
\hline $\mathbf{1}$ & Konstanta & $-1,790$ \\
$\mathbf{2}$ & Kualitas Pelayanan X1 & 0,210 \\
$\mathbf{3}$ & Promosi X2 & 0.280 \\
$\mathbf{4}$ & Harga X3 & 0,380 \\
\hline
\end{tabular}

Sumber : Lampiran 7

Berdasarkan table 4.12 dapat diketahui persamaan regresi yang terbentuk adalah : $\mathrm{Y}=-1,790.0,210 \mathrm{X} 1+0,280 \mathrm{X} 2+0,380 \mathrm{X} 3$

Keterangan :

$\mathrm{Y}=$ Kepuasan Pelanggan

$\mathrm{X} 1=$ Kualitas Pelayanan

$\mathrm{X} 2=$ Promosi

$\mathrm{X} 3=$ Harga

Dari persamaan tersebut dapat diartika bahwa :

a. Konstanta $=-1,790$ menunjukkan besaran kepuasan pelanggan $-1,790$ satuan pada saat kualitas pelayanan, promosi dan harga sama dengan nol.

b. $\mathrm{X}^{1}=$ Hasil $\mathrm{X} 1$ iyalah 2,210 artinya variabel $\mathrm{X} 1$ kualitas pelayanan yang mempunyai nilai 0,210 menunjukkan bahwa variabel kualitas pelayanan mampu meningkatkan kepuasan pelanggan apabila promosi dan harga sama dengan nol. Hal ini juga mengindikasi bahwa kualitas pelayanan berpengaruh positif terhadap kepuasan pelanggan.

c. $\mathrm{X}^{2}=$ Hasil X2 iyalah 0,280 artinya variabel $\mathrm{X} 2$ promosi yang mempengaruhi nilai 0,280 menunjukkan bahwa variabel promosi mampu meningkatkan kepuasan pelanggan apabila kualitas pelayanan dan harga sama dengan nol. Hal ini juga mengindikasikan bahwa promosi berpengaruh positif terhadap kepuasan pelanggan. 
d. $\mathrm{X}^{3}=$ Hasil $\mathrm{X} 3$ iyalah 0,380 artinya variabel $\mathrm{X} 3$ harga yang mempunyai nilai 0,380 menunjukkan bahwa variabel harga mampu menigkatkan kepuasan pelanggan apabila kualitas pelayanan dan promosi sama dengan nol. Hal ini juga mengindikasikan bahwa harga berpengaruh positif terhadap kepuasan pelanggan.

Hipotesis dalam penelitian ini diuji kebenarannya dengan menggunakan uji parsial. Pengujian dilakukan dengan melihat statistic $\mathrm{t}$ hitung dengan statistic $\mathrm{t}$ tabel dan taraf signifikasi ( $p$-value), jika taraf signifikasi yang dihasilkan dari perhitungan di bawah 0,005 maka hipotesis di terima, sebaliknya jika taraf signifikasi hasil hitung lebih besar dari 0,05 maka hipotesis ditolak.

Tabel 4.13 Hasil Uji t

\begin{tabular}{|clcccc}
\hline No & \multicolumn{1}{c}{ Variabel } & $\begin{array}{c}\text { Signifikan } \\
\text { Hitung }\end{array}$ & thitung & ttabel & Keterangan \\
\hline $\mathbf{1}$ & $\begin{array}{l}\text { Kualitas } \\
\text { Pelayanan } \\
(\mathrm{X} 1)\end{array}$ & 0,002 & 3,240 & 1,6666 & Signifikan \\
\hline $\mathbf{2}$ & Promosi (X2) & 0,001 & 3,445 & 1,6666 & Signifikan \\
\hline $\mathbf{3}$ & Harga (X3) & 0,000 & 3,718 & 1,6666 & Signifikan \\
\hline
\end{tabular}

Dari tabel 4.15, diketahui perbandingan antara taraf signifikasi dengan signifikasi tabel adalah sebagai berikut :

1. Hasil uji kualitas pelayanan nilai signifikansi hitung 0,002 dan lebih kecil dari 0,05 dan thitung $(3,240)>t$ tabel $(1,6666)$ yang berarti bahwa hipotesis kualitas pelayanan mempunyai pengaruh signifikan terhadap kepuasan pelanggan pada JNE besuki diterima. Hal ini menunjukkan bahwa H0 ditolak dan $\mathrm{H} 1$ diterima yaitu kualitas pelayanan yang diberikan maka akan berdampak pada semakin baik tingkat kepuasan pelanggan.

2. Hasil uji promosi nilai signifikansi hitung 0,001 dan lebih kecil dari 0,05 dan $t$ hitung $(3,445)>t$ tabel $(1,6666)$ yang berarti bahwa hipotesis promosi mempunyai pengaruh signifikan terhadap kepuasan pelanggan pada JNE besuki diterima. Hal ini menunjukkan bahwa $\mathrm{H} 0$ ditolak dan $\mathrm{H} 2$ diterima yaitu promosi berpengaruh terhadap kepuasan pelanggan yang berarti semakin baik promosi maka akan berdampak semakin baik tingkat kepuasan pelanggan.

3. Hasil uji harga signifikansi hitung 0,000 dan lebih kecil dari 0,05 dan t hitung $(3,718)>\mathrm{t}$ tabel $(1,6666)$ yang berarti bahwa hipotesis harga mempunyai pengaruh signifikan terhadap kepuasan pelanggan pada JNE besuki diterima. Hal ini menunjukkan bahwa $\mathrm{H} 0$ ditolak dan $\mathrm{H} 3$ diterima yaitu harga berpengaruh terhadap kepuasan pelanggan yang berarti semakin baik harga maka akan berdampak pada semakin baik tingkat kepuasan pelanggan. 


\section{Pembahasan}

Berdasarkan hasil pengujian statistic dapat terlihat dengan jelas bahwa secara parsial, semua variabel bebas berpengaruh terhadap variabel terikat. Pengaruh yang diberikan dari ketiga variabel bebas tersebut bersifat positif artinya semakin baik kualitas pelayanan, promosi dan harga maka akan mengakibatkan semakin tinggi pula kepuasan pelanggan. Hasil tersebut sesuai dengan hipotesis yang diajukan. Penjelasan dari masing-masing pengaruh variabel dijelaskan sebagai berikut :

1. Pengaruh Kualitas Pelayanan Terhadap Kepuasan Pelanggan.

Hasil pengujian hipotesis telah membuktikan terdapat pengaruh kualitas pelayanan terhadap kepuasan pelanggan. Melalui hasil perhitungan yang telah dilakukan diperoleh signifikansi sebesar 0,002 dan lebih kecil dari 0,05 dan thitung $3,240>t$ tabel 1,6666 yang berarti hipotesis diterima. Pengajuan secara statistic ini membuktikan bahwa kualitas pelayanan mempunyai pengaruh terhadap kepuasan pelanggan.

Kualitas pelayanan memiliki arti yang sangat penting dalam kepuasan pelanggan. Apabila kualitas pelayanan yang dihasilkan baik maka kepuasan pelanggan pun akan baik. Sebaliknya jika kualitas pelayanan tidak sesuai dengan harapan maka kepuasan pelanggan akan menurun. Untuk mencapai kualitas pelayanan yang diinginkan maka diperlukan suatu standarisasi kualitas pelayanan yang harus diberikan. Di buktikan dengan petugas yang berpenampilan baik dalam melayani, melayani dengan sikap ramah, cepat tanggap dalam melayani dan memberikan jaminan tepat waktu dalam pelayanan. Dari pengertian tersebut, dapat diambil kesimpulan bahwa kualitas pelayanan merupakan suatu keharusan yang harus dimiliki oleh perusahaan baik yang memproduksi barang atau jasa. Ada beberapa pendapat mengenai pengertian kualitas pelayanan yang memiliki berbagai definisi yang berbeda. Kualitas merupkan suatu kondisi yang dinamis yang berhubungan dengan produk jasa manusia, proses dan lingkungan yang memenuhi atau melebihi harapan.

Menurut Tjiptono (2013), pelayanan dapat diartikan sebagai upaya pemenuhan kebutuhan dan keinginan konsumen serta ketepatan penyampaiannya dalam mengimbangi harapan konsumen. Sedangkan menurut Lupiyoadi dan Hamdani (2011) mengatakan kualitas pelayanan adalah derajat yang dicapai oleh karakteristik yang berkaitan dalam memenuhi persyaratan. Menurut Ade Syarif Maulana (2016) kualitas sering dianggap sebagai ukuran relative kebaikan suatu produk atau jasa yang terdiri atas kualitas desain dan kualitas kesesuaian. Kualitas pelayanan adalah tinggat kunggulan yang diharapkan dan pengendalian atas tingkat keunggulan tersebut untuk memenuhi keinginan pelanggan.

Hasil pengujian hipotesis telah membuktikan terdapat pengaruh promosi terhadap kepuasan pelanggan. Melalui hasil perhitungan yang dilakukan diperoleh taraf signifikansi sebesar 0,001 dan lebih kecil dari 0,05 dan t hitung 3,445 > t tabel 1,6666 yang berarti hipotesis diterima. Pengujian secara statistic ini membuktikan bahwa adanya pengaruh promosi terhadap kepuasan pelanggan. 
Promosi merupakan kegiatan yang dilakukan oleh perusahaan untuk mengkomunikasikan manfaat dari produk atau jasa dan meyakinkan konsumen sasaran tentang produk atau jasa yang mereka hasilakan. Semakin sering promosi dilakukan maka akan semakin meningkat pula kepuasan pelanggan yang dirasakan, Sebaliknya jika promosi jarang dilakukan dan kurang baik maka akan menurun pula kepuasan pelanggan yang dirakan. Hal ini dapat dilihat dari JNE memberikan layanan jasa di media social, JNE melakukan promosi melalui instagram dan facebook, JNE melakukan promosi setiap saat, dan JNE malakukan 2-3 kali promosi dalam 1 hari.

Menurut Michael dalam Morrisan (2010), pada dasarnya promosi dilakukan dengan semenarik mungkin yang ditujukan untuk memperkenalkan produk baru juga untuk mempertahankan suatu produk atau jasa yang sedang dipasarkan yang pada akhirnya sasaran promosi itu untuk memperbesar penjualan. Jadi promosi berarti mempertahankan kelangsungan hidup perusahaa. Berbagai upaya dalam melakukan promosi antara lain periklanan, promosi penjualan, dan hubungan masyarakat merupakan hal yang sangat penting dan perlu mempertimbangkan dalam rangka strategi pencapaian tujuan perusahaan. Mengingat tingkat persaingan terus meningkat, maka pihak perusahaan harus meningkatkan kinerja perusahaan dalam berbagai hal. Adakalanya promosi yang optimal yang telah dilakukan perusahaan masih kurang memberikan timbal balik bagi peningkatan konsumen. Setiap pelaku usaha bisnis dituntut untuk memiliki kepekaan terhadap setiap perubahan yang terjadi dan menempatkan orientasi kepada kepuasan konsumen sebagai tujuan utama. Hasil ini mendukung penelitian sebelumnya oleh Nurmalasari (2015) yang menyatakan ada pengaruh promosi terhadap kepuasan pelanggan.

2. Pengaruh Harga Terhadap Kepuasan Pelanggan

Hasil pengujian hipotesis telah membuktikan terdapat pengaruh harga terhadap kepuasan pelanggan. Melalui hasil perhitungan yang telah dilakukan diperoleh taraf signifikan sebesar 0,000 dan lebih kecil dari 0,05 dan thitung 3,718 > t tabel 1,6666 yang berarti hipotesis diterima. Pengujian secara statistic ini membuktikan bahwa tidak ada pengaruh harga dan sesuai dengan kemampuan atau daya beli pelanggan.

Harga sebuah produk atau jasa merupakan faktor penentu dalam permintaan pasar. Harga sebuah produk atau jasa merupakan hal yang sangat penting yang diperhatikan oleh konsumen dalam membeli produk atau jasa. Jika konsumen merasa cocok dengan harga yang ditawarkan, maka mereka akan merasakan kepuasan dalam melakukan pembelian produk atau jasa. Hal ini dapat dilihat dari JNE memiliki harga yang dapat dijangkau, JNE mampu bersaing dengan pengiriman lainnya, dan JNE mempunyai kesesuaian dengan kualitas pelayanan yang diberikan.

Menurut Tjiptono dan Chandra (2012) menyatakan bahwa harga adalah satuan moneter atau ukuran lainnya (termasuk barang dan jasa lainnya) yang ditukarkan agar memperoleh hak kepemilikan atau penggunaan suatu barang atau jasa. Jadi bisa dikatakan harga tergantung pada kemampuan 
berneegosiasi dari pihak penjual dan pembeli untuk memperoleh harga kesepakatan yang sesuai dengan masing-masing pihak, sehingga pada awalnya pihak penjual akan menetapkan harga yang tinggi dan pembeli akan menetapkan harga terendah. Harga sebuah produk atau jasa merupakan faktor penentu dalam permintaan pasar. Harga merupakan hal yang sangat penting yang diperhatikan oleh konsumen dalam membeli produk atau jasa. Jika konsumen merasa cocok dengan harga yang ditawarkan, maka mereka akan cenderung melakukan pembelian ulang untuk produk yang sama. Dalam teori ekonomi disebutkan bahwa harga suatu barang atau jasa yang pasarnya kompetitif, maka tinggi rendahnya harga ditentukan oleh permintaan dan penawaran pasar.

\section{KESIMPULAN}

Dari pemgujian statistic yang telah dilakukan, maka hasil penelitian ini dapat disimpulakn sebagai berikut :

1. Kualitas pelayanan berpengaruh terhadp kepuasan pelanggan, hasil temuan ini berarti semakin baik kualitas pelayanan maka akan meningkatkan kepuasan pelanggan.

2. Promosi berpengaruh terhadap kepuasan pelanggan, hasil temuan ii berarti semakin baik promosi makan akan meningkatkan kepuasan pelanggan.

3. Harga berpegaruh terhadap kepuasan pelanggan, hasil temuan ini berarti semakin baik harga makan akan meningkatkan kepuasan pelanggan.

\section{SARAN}

Berdasarkan analisis hasil penelitian, pembahasan dan kesimpulan yang telah dikemukakan sebelumnya terdapat beberapa saran sebagai berikut :

1. Bagi Ilmu Pengetahuan Hasil penelitian ini dapat memberikan sumbangsih ilmu pengetahuan terhadap perkembangan ilmu Manajemen Pemasaran khususnya tentang kualitas pelayanan, promosi dan harga terhadap kepuasan pelanggan pada jasa pengiriman barang JNE di besuki sehingga dapat meningkatkan profit pada JNE cabang besuki.

2. Bagi Pihak JNE Cabang Besuki

a. Diharapkan pihak JNE mampu menjaga komunikasi yang baik dengan para konsumen yang baru atau pun lama, upaya ini untuk meyakinkan para konsumen agar tetap menggunakan jasa layanan JNE.

b. Dalam upaya menjaga kepuasan pelanggan maka pihak JNE harus selalu menjaga setiap kualitas pelayanannya dan selalu melakukan promosi serta memberikan harga yang bisa menjamin kepada setiap pelanggan JNE.

c. Diharapkan bagi setiap karyawan JNE agar selalu bersikap ramah, sopan dan tanggap terhadap para konsumen.

3. Bagi Peneliti yang akan datang

Penelitian ini dapat digunakan sebagai referensi atau acuan terhadap 
peneliti yang akan datang dengan tema yang sejenis. Peneliti selajutnya diharapkan untuk dapat mengembangkan wawasan lagi yang kaitannya dengan penemuan indikato-indikator.

\section{DAFTAR PUSTAKA}

Anggriana, R., Qomariah, N., \& Santoso, B. (2017). Pengaruh Harga, Promosi, Kualitas Layanan Terhadap Kepuasan Pelanggan Jasa Ojek Online “OM-JEK” Jember. Jurnal Sains Manajemen Dan Bisnis Indonesia, 7(2), 137-156. http://jurnal.unmuhjember.ac.id/index.php/SMBI/article/view/1229/989

Ade Syarif Maulana, Pengaruh Kualitas Pelayanan dan Harga terhadap Kepuasan Pelanggan PT. TOI, Jurnal Ekonomi Volime 7 Nomor 2, November 2016

Handoko, B. (2017). Pengaruh Promosi, Harga Dan Kualitas Pelayanan Terhadap Kepuasan Konsumen Pada Titipan Kilat JNE Medan. Jurnal Ilmiah Manajemen Dan Bisnis, 18(1), 61-72. https://doi.org/10.30596/jimb.v18i1.1098

Ilmu, J., \& Manajemen, R. (2019). KUALITAS PELAYANAN DAN PROMOSI TERHADAP LOYALITAS KONSUMEN DI MEDIASI KEPUASAN KONSUMEN JASA PENGIRIMAN PT POS INDONESIA ( PERSERO ) DI SURABAYA

Kurniawati, T., \& Hery, I. S. P. (2019). Promosi Dan Keputusan Penggunaan Jasa Jalur Nugraha Ekakurir (JNE) Bagi Pedagang Online di Kecamatan Masaran Kabupaten Sragen. Ekonomi Paradigma, 20(1), 55-59.

Lindung Bulan, T. (2016). Pengaruh Kualitas Pelayanan dan Harga terhadap Loyalitas Konsumen pada PT. Tiki Jalur Nugraha Ekakurir Agen Kota Langsa. Jurnal Manajemen Dan Keuangan Unsam, 5(2), 592-602.

Nurlina, Milasari, \& Indah, D. R. (2019). Pengaruh Kualitas Pelayanan, Harga dan Lokasi terhadap Keputusan Penggunaan Jasa Pengiriman Barang PT. Citra Van Titipan Kilat Kota Langsa. Jurnal Samudra Ekonomika, 3(1), 1-8.

Noeraini, I. A. (2016). Pengaruh Tingkat Kepercayaan, Kualitas Pelayanan, dan Harga Terhadap Kepuasan Pelanggan JNE Surabaya. Ilmu Dan Riset Manajemen, ISSN: 2461-0593, 5(5), 1-17.

Surianto, K. N., \& Istriani, E. (2019). Pengaruh Kualitas Pelayanan, Persepsi Harga Dan Promosi Terhadap Kepuasan Pelanggan Pengguna Jasa Transportasi Online GrabCardi Yogyakarta. 978-979.

Agus Sulastiyono (2006). Manajemen Penyelenggaraan Hotel. Bandung; Alfabeta.

Arikunto, S. 2006. Metode Penelitian Kualitatif. Jakarta: Bumi Aksara 
Basu Swastha \& Irawan. 2005 Manajemen Pemasaran Modern. Liberty, Yogyakarta.

E. Jerome Mc.Carthy dan William D. Perreault, Jr. 2003. Dasar-Dasar Penelitian, Penerbit Erlangga, Jakarta.

Fandy Tjiptono. 2006. Manajemen Jasa. Edisi Pertama. Yogyakarta : Andi

Fandy Tjiptono 2009, Strategi Pemasaran, edisi kedua, cetakan ketujuh, Penerbit : Andi Offset, Yogyakarta

Fandy, Tjiptono dan Greforius, Chandra. (2016). Pemasaran Jasa (Prinsip, Penerapan, dan Penelitian), Yogyakarta: Andi.

Fandy, Tjiptono. 1998. Peranan Desain Kemasan Dalam Dunia Pemasaran. Yogyakarta: Andi.

Hasan, M. Iqbal, Pokok-pokok Materi Metodologi Penelitian dan Aplikasinya, Ghalia Indonesia, Bogor, 2002.

Hurriyati, Ratih. (2015). Bauran Pemasaran dan Loyalitas Konsumen.Bandung: ALFABETHA

Kasmir \& Jakfar. 2012. Studi Kelayakan Bisnis. Cetakan ke Delapan. Jakarta: Kencana.

Kotler Dan Keller, (2015), Manajemen Pemasaran, Jilid 1, Edisi 13, Jakarta: Erlangga

Kotler dan Keller, 2007. Manajemen Pemasaran, Edisi 12, Jilid 1, PT.Indeks, Jakarta.

Kotler, Philip and Kevin Lane Keller, (2016): Marketing Management, 15th Edition New Jersey: Pearson Pretice Hall, Inc.

Kotler, Philip. 2008. Manajemen Pemasaran Edisi 12 Jilid 2. Jakarta: Indeks

Laksana, Fajar. 2008. Manajemen Pemasaran. Yogyakarta: Graha Ilmu.

Lupiyoadi dan Hamdani, 2006. Manajemen Pemasaran jasa Edisi kedua.

Parasuraman, A., Zeithaml, V.A.and Berry, L.L. (1998), SERVQUAL: a multiple item scale for Measuring consumer perceptions of service quality, Journal of Retaling, vol. 64 No, 1, pp. 12-40.

Philip Kotler, 2002, Manajemen Pemasaran, Edisi Millenium, Jilid 2, PT Prenhallindo, Jakarta 
Situmorang, S. H. (2008). Analisis Data Penelitian. Cetakan Kedua. Medan: USU Press.

Sudjarwo dan Basrowi. (2009). Manajemen Penelitian Sosial. Bandung: CV. Mandar Maju

Sugiyono. 2010. Metode Penelitian Pendidikan Pendekatan Kuantitatif, kualitatif, dan $R \& D$. Bandung: Alfabeta

Sugiyono. 2012.Metode Penelitian Bisnis. Bandung : Alfabeta.

Sugiyono. 2013. Metode Penelitian Pendidikan Pendekatan Kuantitatif, Kualitatif, dan $R \& D$. Bandung: Alfabeta.

Sugiyono, Endar. 2004. Pengaruh Persepsi Produk, Harga dan Promosi Terhadap Omset Penjualan Pada Industri Kecil Keramik Di Kec. Banjarharjo Kab. Brebes. Skripsi, UNNES.

Setiawati, E. K. A. R. (2017). Jom FISIP Volume 4 No. 1 Februari 2017 Page 1. 4(1), 113.

Tjiptono, Fandy \& Gregorius, C.(2006). Service Quality \& Satisfaction. Yogyakarta: Andi Offset

Wijayanti, L. M., Hyun, C. C., \& Putri, R. S. (2020). Jurnal Manajemen Oikonomia. Jurnal Manajemen, 16(1), 1-13. 